\title{
EFFECTS OF ORGANIC AND INORGANIC FERTILIZERS ON LETTUCE (Lactuca sativa L.) AND SOIL PROPERTIES
}

\author{
M.B. Hossain ${ }^{1 *}$ and K.S. Ryu ${ }^{2}$ \\ ${ }^{1}$ Soil Science Division, Bangladesh Institute of Nuclear Agriculture, Mymensingh-2200, Bangladesh \\ ${ }^{2}$ Laboratory of Soil Science, Department of Food and Bioenvironmental Science, College of Life \& \\ Environment, Daegu University, Kyongsan, Kyongbuk, Korea-712714, Republic of Korea
}

\begin{abstract}
A Greenhouse experiment was conducted to identify the suitable dose of organic fertilizer for lettuce production. Different doses of organic fertilizer $\left(6.5,13\right.$ and $\left.26 \mathrm{t} \mathrm{ha}^{-1}\right)$ and the recommended dose of chemical fertilizer (RDCF) as standard were selected for this experiment. Application of $13 \mathrm{t} \mathrm{ha}^{-1}$ organic fertilizer significantly increased leaf size (length and breadth) of lettuce. This treatment also increased 14, 25, 21, $32,24,27,36$ and $168 \%$ fresh weight, dry weight, N, P, K, Ca, Mg \& Na uptake over RDCF, respectively. Organic matter content was increased of $17.79,43.82$ and $89.89 \%$ in $6.5,13$ and $26 \mathrm{t} \mathrm{ha}^{-1}$ organic fertilizer treated plots respectively over recommended dose of chemical fertilizers. Data also indicated that organic fertilizer @ $26 \mathrm{t} \mathrm{ha}^{-1}$ resulted in significant increase in $\mathrm{pH}$, total nitrogen $(24 \%)$, organic matter $(90 \%)$ and $\mathrm{Zn}(29 \%)$ compared to RDCF and decreased electrical conductivity, mineral nitrogen $\left(\mathrm{NH}_{4}{ }^{+}-\mathrm{N} \& \mathrm{NO}_{3}{ }^{-} \mathrm{N}\right)$ and cadmium and lead $(\mathrm{Cd} \& \mathrm{~Pb})$ in soil. Positive and significant correlation was observed on yield and yield attributes of lettuce and soil nitrogen, organic matter with $\mathrm{pH}$, total nitrogen with mineral nitrogen and negative correlation was found with applied organic fertilizer with cadmium and lead. Based on these results, organic fertilizer @ $13 \mathrm{t} \mathrm{ha}^{-1}$ without chemical fertilizer could be recommended to increase lettuce yield as well as mitigate heavy metals in soil.
\end{abstract}

Keywords: Organic fertilizer doses, lettuce yield, nutrient uptake, soil chemical properties

\section{INTRODUCTION}

Lettuce is one of the most important commercial vegetables and major food items in Republic of Korea. It is consumed as salad and a fast food item. As such it assumes importance to carry out research in order to optimize the production of lettuce and also guarantee the environmental sustainability in crop production areas. Crops

\footnotetext{
*Corresponding author e-mail: belalbina@gmail.com
} 
success depends on nutrient input during growth. Sole use of chemical fertilizers often declines soil fertility and the resultant crop productivity due to nutrient imbalance in soil, which has been recognized as one of the most important factors that limit crop yield. Therefore, the use of chemical fertilizer may not keep pace with time in maintenance of soil health for sustaining the productivity. Every day increases the concern with food intake that received excessive chemical molecules when consumed outside the prudential limits cause disease in the short and long term (Moreira et al., 2014). Lettuce is actually consumed in natural and as such consumers' concern has been steadily increasing how it is cropped and parallel to this fact is that there is an increasing demand for organic products. The use of mineral fertilizers in lettuce growth is a common agricultural practice that brings satisfactory results in terms of yield, however, consumer's health, production cost and product quality should be considered. Organic farming practices involved on the management of soil organic matter (SOM) and nutrient availability include crop rotation, cover cropping and soil amendment with compost and/or manures (Brito et al., 2012). Organic fertilizers also improve soil physical and chemical properties and reduce the needs for mineral fertilizers. The application of organic fertilizers in lettuce increases the yield and nutrient content in plants. Knowing that leafy vegetables respond well to organic manure results obtained from an experiment with arugula and lettuce, concluded that organic matter mineralization contributed for nutrients to plants supplying their needs during development, because the area was managed with organic practices about five years (Oliveira et al., 2010). Organic compound has a positive effect on fresh weight plant as pointed by an experiment (Villas Boase et al., 2004), which tested three doses (30, 60 and $\left.120 \mathrm{t} \mathrm{ha}^{-1}\right)$. It could be observed that the compound bean straw increased fresh weight of plant and the values of $\mathrm{N}, \mathrm{K}, \mathrm{Ca}, \mathrm{Mg}$, $\mathrm{Cu}, \mathrm{Fe} \& \mathrm{Zn}$ in lettuce plants (Vilas et al., 2004). This study aimed at evaluating the effect of compost rates and recommended dose of mineral (RDM) fertilizers on lettuce (Lactuca sativa L.) and soil properties.

\section{MATERIALS AND METHODS}

A controlled glasshouse experiment was conducted at Daegu University, Kyongsan, Daegu in Republic of Korea to compare the performance of organic fertilizer doses and recommended dose of chemical fertilizers (RDCF) on growth and yield of lettuce, nutrient uptake and their effect on soil chemical properties. Glasshouse controller was maintained to monitor and control temperature $\left(15-25^{\circ} \mathrm{C}\right)$, lighting $\left(250 \mu \mathrm{mol} \mathrm{m} \mathrm{mec}^{-1}\right)$ and humidity $(65-95 \%) . \mathrm{CO}_{2}$ monitoring control was used for the experiment. Initial soil samples were collected from the experimental and mixed it after final land preparation. Initial soil and organic fertilizer properties are presented in table 1 . 
Table 1. Physical and chemical properties of soil and organic fertilizer

\begin{tabular}{lll}
\hline Parameters & Soil & Organic fertilizer \\
\hline & & \\
Textural class & Silt loam & \\
Soil reaction $(\mathrm{pH})$ & 7.3 & \\
Electrical conductivity $\left(\mathrm{dS} \mathrm{m}^{-1}\right)$ & 0.3 & \\
Organic matter $(\%)$ & 9.8 & $0.45 \%$ (total nitrogen) \\
Total nitrogen $(\%)$ & 0.19 & $0.14 \%$ (total phosphorus ) \\
Available $\mathrm{P}_{2} \mathrm{O}_{5}\left(\mathrm{mg} \mathrm{kg}^{-1}\right)$ & 370 & \\
Exchangeable $\mathrm{K}\left(\mathrm{cmole}_{\mathrm{c}} \mathrm{kg}^{-1}\right)$ & 2.2 & \\
Exchangeable Ca $\left(\mathrm{cmole}_{\mathrm{c}} \mathrm{kg}^{-1}\right)$ & 15.4 & \\
Exchangeable $\mathrm{Mg}\left(\mathrm{cmole}_{\mathrm{c}} \mathrm{kg}^{-1}\right)$ & 0.06 & \\
Cadmium $\left(\mathrm{cmolec} \mathrm{kg}^{-1}\right)$ & $\mathrm{nd}$ & \\
Cupper $\left(\mathrm{cmole}_{\mathrm{c}} \mathrm{kg}^{-1}\right)$ & 1.54 & \\
Lead $\left(\mathrm{cmole}_{\mathrm{c}} \mathrm{kg}^{-1}\right)$ & 0.42 & \\
Zinc $\left(\mathrm{cmole}_{\mathrm{c}} \mathrm{kg}^{-1}\right)$ & 17.46 & \\
\hline
\end{tabular}

nd=non-detectable.

Four treatments comprised of recommended dose of chemical fertilizers (RDCF) (urea, fused super phosphate and muriate of potash @ 440, 500 and $250 \mathrm{~kg} \mathrm{ha}^{-1}$, respectively), $50 \%$ recommended dose of organic fertilizer $\left(6.5 \mathrm{t} \mathrm{ha}^{-1}\right), 100 \%$ recommended dose of organic fertilizer $\left(13 \mathrm{t} \mathrm{ha}^{-1}\right)$ and $200 \%$ recommended dose of organic fertilizer $\left(26 \mathrm{t} \mathrm{ha}^{-1}\right)$. Field experiment was laid out in a randomized block design with three replications in a plot size of $2.5 \mathrm{~m} \times 4 \mathrm{~m}$. Lettuce was the test crop used in the experiment. Row to row and plant to plant distances were $30 \mathrm{~cm} \times 25 \mathrm{~cm}$. Half dose of nitrogen as urea, full dose of fused super phosphate and muriate of potash were applied as basal and the remaining half dose of urea was applied after 20 days from the date of lettuce plantation. The crop was cultivated following normal cultural practices. Soil samples were collected from the experimental plots after harvest of lettuce. These samples were dried, powdered and sieved through $2 \mathrm{~mm}$ sieve for analysis of $\mathrm{pH}$, organic carbon, total nitrogen, $\mathrm{EC}, \mathrm{Cd}, \mathrm{Pb}, \mathrm{Cu}$ and $\mathrm{Zn}$. The $\mathrm{pH}$ of soil samples was measured in 1:2.5 soils: distilled water suspension with the help of $\mathrm{pH}$ meter and organic carbon was measured by chromic acid digestion method (Walkley and Black, 1934). Electrical conductivity (EC), Cadmium (Cd), Cupper $(\mathrm{Cu})$, lead $(\mathrm{Pd})$, and Zinc $(\mathrm{Zn})$ were analyzed by the following standard methods. Harvested plants were washed, dried and ground by using a stainless steel mill and then digested with tri-acid $\left(\mathrm{HNO}_{3}-\mathrm{HClO}_{4}-\mathrm{H}_{2} \mathrm{SO}_{4}\right)$ mixture. $\mathrm{P}, \mathrm{K}, \mathrm{Ca}, \mathrm{Mg}$, 
and $\mathrm{Na}$ in soil solution and plant extracts except nitrogen were analyzed by ICP-AES (Inductively coupled plasma-atomic emission spectrometer) using a Varian Liberty Series II, Aus. $\mathrm{NH}_{4}{ }^{+}-\mathrm{N}$ and $\mathrm{NO}_{3}{ }^{-}-\mathrm{N}$ were determined by steam distillation of $\mathrm{K}_{2} \mathrm{SO}_{4}$ extract using $\mathrm{MgO}$ and Deverda's alloy, respectively (Bremner, 1965). Data were statistically analyzed and Duncan's Multiple Range was applied to examine significant differences between the treatment means (Gomez and Gomez, 1984).

\section{RESULTS}

Data regarding the effect of organic fertilizer rates and the recommended dose of chemical fertilizers (RDCF) on plant height, leaf number, leaf length and breadth are summarized in table 2. Organic fertilizer doses $\left(6.5,13\right.$ and $\left.26 \mathrm{tha}^{-1}\right)$ and RDCF did not produce significant results except leaf number of lettuce. Plant height of lettuce was found higher in most of the treatments except $26 \mathrm{t} \mathrm{ha}^{-1}$ organic fertilizer treatment but the differences were not significant. It was found that application of organic fertilizer $\left(13 \mathrm{t} \mathrm{ha}^{-1}\right)$ resulted in significantly greater of $9.2 \%$ and $8.3 \%$ plant height compared with $26 \mathrm{t} \mathrm{ha}^{-1}$ organic fertilizer rate and RDCF, respectively. Leaf number is known as primary yield attribute, which also plays an important role in yield formation of lettuce. Leaf number ranged from 21.5 to 23.90 in different treatments. Application of $13 \mathrm{t} \mathrm{ha}^{-1}$ organic fertilizer also produced the maximum leaf number and size of lettuce, which followed by the application of $6.5 \mathrm{t} \mathrm{ha}^{-1}$ organic fertilizer. All the organic fertilizer doses produced the higher leaf number than RDCF. Leaf size in respect of leaf length and breadth, organic fertilizer @ $13 \mathrm{tha}^{-1}$ produced the maximum leaf size $(22.97 \mathrm{~cm} \times 11.69 \mathrm{~cm})$, while the treatment organic fertilizer $\left(26 \mathrm{t} \mathrm{ha}^{-1}\right)$ and the RDCF had the smallest leaf size. Organic fertilizer @ $26 \mathrm{t}$ ha $^{-1}$ produced lower leaf length $(21.85 \mathrm{~cm})$ than RDCF and the opposite results were found in respect of leaf breadth in these treatments. Mean dry weight of lettuce ranged 0.76 and $0.95 \mathrm{t} \mathrm{ha}^{-1}$ in RDCF and organic fertilizer $\left(13 \mathrm{t} \mathrm{ha}^{-1}\right)$, respectively. Among the organic fertilizer doses, $13 \mathrm{t} \mathrm{ha}^{-1}$ accounted for higher yield with an increase of 25 percent over RDCF. Further increase in organic fertilizer dose resulted in yield reduction of lettuce. Organic fertilizer dose $13 \mathrm{t} \mathrm{ha}^{-1}$ also performed better lettuce yield than $6.5 \mathrm{t} \mathrm{ha}^{-1}$ treated plots. However, the plot supplied with $26 \mathrm{t} \mathrm{ha}^{-1}$ could not sustain the yield until the amount of organic fertilizer was increased from $13 \mathrm{t} \mathrm{ha}^{-1}$. Organic fertilizer applied @ $13 \mathrm{t} \mathrm{ha}^{-1}$ also significantly increased fresh weight of lettuce by 7.0 and 22.4 percent over organic fertilizers applied @ 6.5 and $26 \mathrm{t} \mathrm{ha}^{-1}$, respectively. Effects of organic fertilizer doses and RDCF on N, P, K, Ca, $\mathrm{Mg} \& \mathrm{Na}$ uptake of lettuce are summarized in table 2. N, P, Ca, Mg \& Na uptake results were statistically significant in different treatments. Maximum $\mathrm{N}$ uptake was observed in $13 \mathrm{t} \mathrm{ha}^{-1}$ organic fertilizer followed by $6.5 \mathrm{t} \mathrm{ha}^{-1}$ organic fertilizer. Nitrogen uptake was increased with increasing of organic fertilizer rates and such increases were found significantly higher up to $13 \mathrm{t} \mathrm{ha}^{-1}$ organic fertilizers applied. Similar trend was observed in respect of P and K uptake by lettuce. Potassium uptake was higher than any other nutrients studied in the experiment but the uptake results 
were not statistically significant in different treatments. Its uptake ranged from 74.50 to $92.25 \mathrm{~kg} \mathrm{ha}^{-1}$ in RDCF and $13 \mathrm{t} \mathrm{ha}^{-1}$ organic fertilizers treated plots, respectively. Potassium uptake was increased from 9.96, 19.24 and 6.58 percent in $6.5,13$ and $26 \mathrm{t}$ $\mathrm{ha}^{-1}$ applied organic fertilizer rates over RDCF. Maximum Ca and $\mathrm{Mg}$ uptake were found in $13 \mathrm{t} \mathrm{ha}^{-1}$ organic fertilizer treated plots and the second highest calcium $(\mathrm{Ca})$ and magnesium $(\mathrm{Mg})$ uptake was found in $6.5 \mathrm{t} \mathrm{ha}^{-1}$ organic fertilizer. On the other hand, organic fertilizer $\left(6.5 \mathrm{tha}^{-1}\right)$ produced the highest Na uptake in lettuce leaf and the lowest Na uptake was found in RDCF.

Effects of organic fertilizer rates and RDCF on chemical properties of soil are summarized in table 3 . Soil reaction was increased with the increase of organic fertilizer doses. Soil $\mathrm{pH}$ varied from 6.83 to 7.93 . The lowest $\mathrm{pH}$ was recorded in $\mathrm{RDCF}$ treated plots and the highest $\mathrm{pH}$ was observed in $26 \mathrm{t} \mathrm{ha}^{-1}$ organic fertilizer treated plots. Same pH (7.87) was found in 6.5 and $13 \mathrm{t} \mathrm{ha}^{-1}$ levels. The use of organic fertilizer $\left(6.5,13\right.$ and $\left.26 \mathrm{t} \mathrm{ha}^{-1}\right)$ decreased the potential acidity from 15.2 to $16.7 \%$ compared to RDCF, indicating that organic fertilizer promoted the increase of bases in soil exchange complex. Electrical conductivity (EC) results were not statistically significant in different treatments (Table 3). Maximum EC $\left(0.22 \mathrm{dS} \mathrm{m}^{-1}\right)$ was observed in RDCF treated plots. Recommended doses of RDCF produced higher EC value than different doses of organic fertilizer. Same EC value $\left(0.13 \mathrm{dS} \mathrm{m}^{-1}\right)$ was found in 13 and $26 \mathrm{tha}^{-1}$ organic fertilizer doses. Total nitrogen ranged from $0.16 \%$ in $6.5 \mathrm{t} \mathrm{ha}^{-1}$ to $0.21 \%$ supplied with organic fertilizer @ $26 \mathrm{t} \mathrm{ha}^{-1}$. Available nitrogen content results were not statistically significant. In general, organic fertilizer 6.5 and $13 \mathrm{t} \mathrm{ha}^{-1}$ increased 21 and 26 percent $\mathrm{NH}_{4}{ }^{+} \mathrm{N}$ and 11 and 19 percent $\mathrm{NO}_{3}{ }^{-}-\mathrm{N}$ over RDCF, respectively. On the other hand, RDCF treated plots increased 81 and 50 percent $\mathrm{NH}_{4}{ }^{+}-\mathrm{N}$ and $\mathrm{NO}_{3}{ }^{-}-\mathrm{N}$ over the $26 \mathrm{t} \mathrm{ha}^{-1}$ organic fertilizer respectively. Available $\mathrm{N}\left(\mathrm{NH}_{4}{ }^{+}-\mathrm{N}\right.$ and $\left.\mathrm{NO}_{3}{ }^{-}-\mathrm{N}\right)$ content was increased with the increase of organic fertilizer rates except $26 \mathrm{t} \mathrm{ha}^{-1}$. Ammonium-N $\left(\mathrm{NH}_{4}{ }^{+}-\mathrm{N}\right)$ content was higher than $\mathrm{NO}_{3}{ }^{-}-\mathrm{N}$ except $26 \mathrm{t} \mathrm{ha}^{-1}$ organic fertilizer treated plots. Different treatments had significant effect on soil organic matter status in soil. Organic matter in soil was varied from 0.89 to 1.69 per cent. The lowest organic matter was recorded in RDCF and the highest was in $26 \mathrm{t} \mathrm{ha}^{-1}$ organic fertilizer treated plots. Organic matter content was also increased of $17.79,43.82$ and $89.89 \%$ in $6.5,13$ and $26 \mathrm{t} \mathrm{ha}^{-1}$ organic fertilizer treated plots respectively over RDCF. Organic matter was increased with the increase of organic fertilizer doses and such increases were found significantly higher up to $26 \mathrm{t} \mathrm{ha}^{-1}$. Heavy metals $(\mathrm{Cd} \mathrm{\&} \mathrm{Pb})$ were decreased with the increase of organic fertilizer doses. Organic fertilizer $\left(26 \mathrm{t} \mathrm{ha}^{-1}\right)$ helped to reduce heavy metals contents in soil except $\mathrm{Zn}$. Maximum heavy metals concentrations were found in RDCF treated plots. Zinc content was increased with the increase of organic fertilizer level. Correlation coefficients of yield attributes and soil quality traits were worked out (Figure 1a, b, c, d, e, f, g, h \& i) in order to evaluate their influence on lettuce yield. Plant height, leaf number, $\mathrm{NH}_{4}{ }^{+}-\mathrm{N}$ and $\mathrm{NO}_{3}^{-}-\mathrm{N}$ content were performed 
Table 2. Effect of different levels of organic fertilizer and mineral fertilizer on growth, yield and nutrient uptake of lettuce

\begin{tabular}{|c|c|c|c|c|c|c|c|c|c|c|c|c|}
\hline Treatment & $\begin{array}{l}\text { Plant } \\
\text { height } \\
(\mathrm{cm})\end{array}$ & $\begin{array}{c}\text { No. of } \\
\text { leaf }\end{array}$ & \multicolumn{2}{|c|}{ Leaf size $(\mathrm{cm})$} & $\begin{array}{c}\text { Fresh } \\
\text { weight }(\mathrm{t} \\
\left.\text { ha }^{-1}\right)\end{array}$ & $\begin{array}{c}\text { Dry } \\
\text { weight } \\
\left(\mathrm{t} \mathrm{ha}^{-1}\right)\end{array}$ & $\mathrm{N}$ & $\mathrm{P}$ & K & $\mathrm{Ca}$ & $\mathrm{Mg}$ & $\mathrm{Na}$ \\
\hline Organic fertilizer $\left(6.5 \mathrm{t} \mathrm{ha}^{-1}\right)$ & 28.68 & 22.77 & 22.37 & 11.40 & 1.98 & 0.93 & 33.73 & 5.98 & 82.74 & 15.93 & 4.03 & 5.58 \\
\hline Organic fertilizer $\left(13 \mathrm{t} \mathrm{ha}^{-1}\right)$ & 29.23 & 23.90 & 22.97 & 11.69 & 2.10 & 0.95 & 34.71 & 6.81 & 92.25 & 18.51 & 4.09 & 5.17 \\
\hline $\mathrm{LSD}_{0.05}$ & NS & 2.21 & NS & NS & 0.11 & 0.07 & 3.95 & 1.42 & NS & 2.52 & 1.00 & 3.21 \\
\hline
\end{tabular}

LSD=Least Significant Difference.

Table 3. Effect of different levels of organic fertilizer and mineral fertilizer on chemical properties in post harvest soil

\begin{tabular}{|c|c|c|c|c|c|c|c|c|c|}
\hline \multirow[t]{2}{*}{ Treatment } & \multirow[t]{2}{*}{$\mathrm{pH}$} & \multirow[t]{2}{*}{$\begin{array}{c}\mathrm{EC} \\
\mathrm{dS} \mathrm{m}^{-1}\end{array}$} & \multirow{2}{*}{$\begin{array}{l}\text { Total } \\
\text { nitrogen } \\
\quad(\%)\end{array}$} & \multicolumn{2}{|c|}{$\begin{array}{l}\text { Mineral nitrogen } \\
\quad(\mathrm{ppm})\end{array}$} & \multirow{2}{*}{$\begin{array}{l}\text { Organic } \\
\text { matter } \\
(\%)\end{array}$} & \multicolumn{3}{|c|}{ Heavy metals (ppm) } \\
\hline & & & & $\mathrm{NH}_{4}^{+}-\mathrm{N}$ & $\mathrm{NO}_{3}^{-}-\mathrm{N}$ & & $\mathrm{Cd}$ & $\mathrm{Pd}$ & $\mathrm{Zn}$ \\
\hline Chemical fertilizers (RDCF) & 6.83 & 0.22 & 0.17 & 22.17 & 21.00 & 0.89 & 1.74 & 0.43 & 14.12 \\
\hline Organic fertilizer $\left(6.5 \mathrm{t} \mathrm{ha}^{-1}\right)$ & 7.87 & 0.12 & 0.16 & 26.83 & 23.33 & 1.05 & 1.36 & 0.41 & 15.30 \\
\hline Organic fertilizer $\left(13 \mathrm{tha}^{-1}\right)$ & 7.87 & 0.13 & 0.18 & 28.00 & 25.00 & 1.28 & 0.98 & 0.37 & 16.39 \\
\hline Organic fertilizer $\left(26 \mathrm{t} \mathrm{ha}^{-1}\right)$ & 7.97 & 0.13 & 0.21 & 12.25 & 14.91 & 1.69 & 0.43 & 0.06 & 18.28 \\
\hline $\mathrm{LSD}_{0.05}$ & 0.30 & NS & NS & NS & NS & 0.13 & 0.22 & NS & 3.71 \\
\hline
\end{tabular}

LSD=Least Significant Difference. 
positive and significant correlation with lettuce yield to indicate that lettuce yield was increased with the increase of the above mentioned parameters. Soil $\mathrm{pH}$ had positive and significant correlation with organic matter $(\mathrm{OM})$ content in soil suggesting that increased OM helped to increase $\mathrm{pH}$ in soil. On the other hand, $\mathrm{NH}_{4}{ }^{+}-\mathrm{N}$ and $\mathrm{NO}_{3}{ }^{-} \mathrm{N}$ contents were decreased with the increase of total nitrogen in soil. A negative and significant correlation was observed between organic fertilizer doses and heavy metals $(\mathrm{Cd} \& \mathrm{~Pb})$. Heavy metals decreased with the increase of organic fertilizer doses. Plant height $\left(r^{2}=0.973\right)$, leaf number $\left(r^{2}=0.486\right), \mathrm{NH}_{4}{ }^{+}-\mathrm{N}$ content $\left(r^{2}=0.970\right)$, $\mathrm{NO}_{3}{ }^{-}-\mathrm{N}$ content $\left(\mathrm{r}^{2}=0.797\right)$ showed significant positive correlation with yield of lettuce. On the other hand, total nitrogen showed significant negative correlation with $\mathrm{NH}_{4}{ }^{+}-\mathrm{N}$ content $\left(\mathrm{r}^{2}=0.834\right)$ and $\mathrm{NO}_{3}{ }^{-}-\mathrm{N}$ content $\left(\mathrm{r}^{2}=0.830\right)$. From regression studies it was clear that available mineral nitrogen performed significant effect on growth of lettuce. Organic fertilizer (@ 6.5 and $13 \mathrm{t} \mathrm{ha}^{-1}$ ) plots increased available nitrogen in soil.
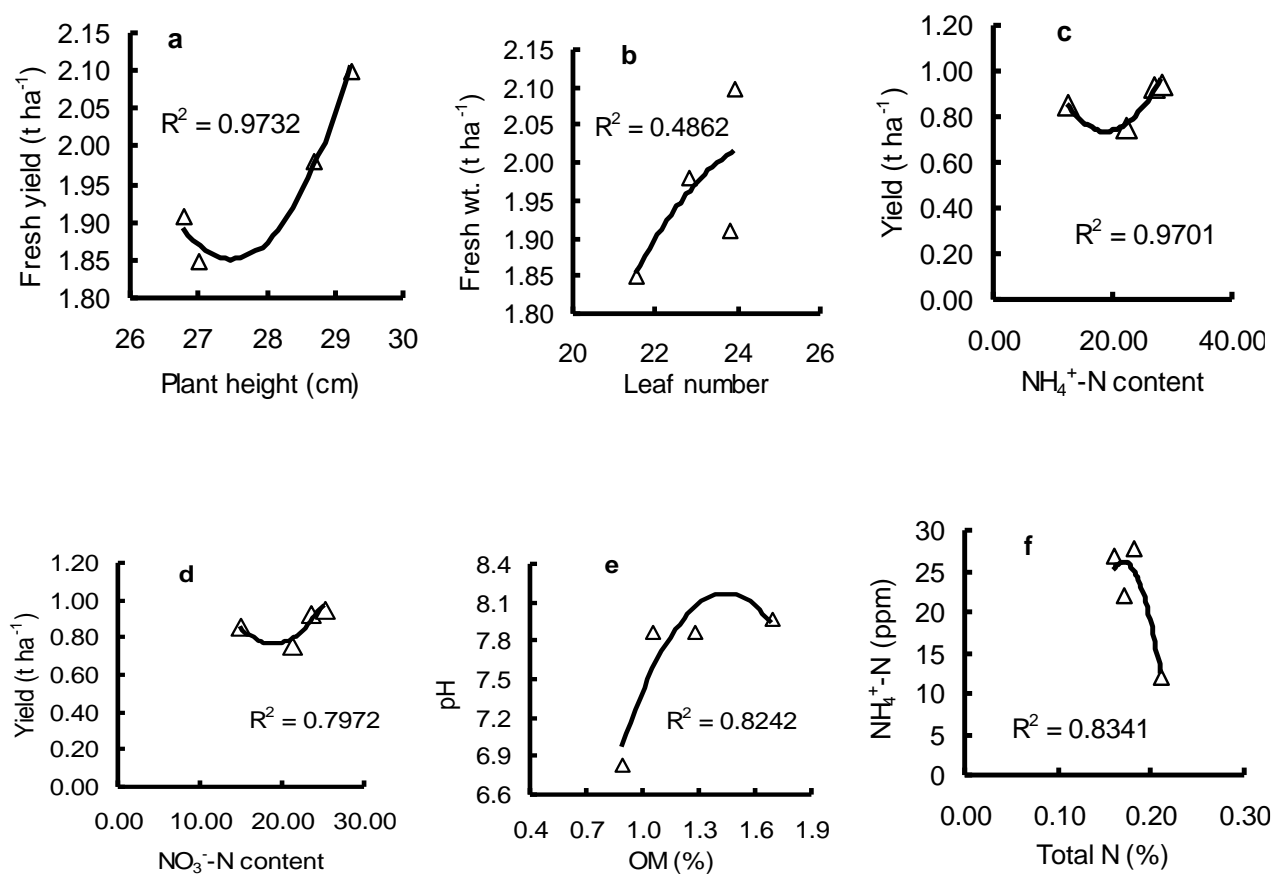

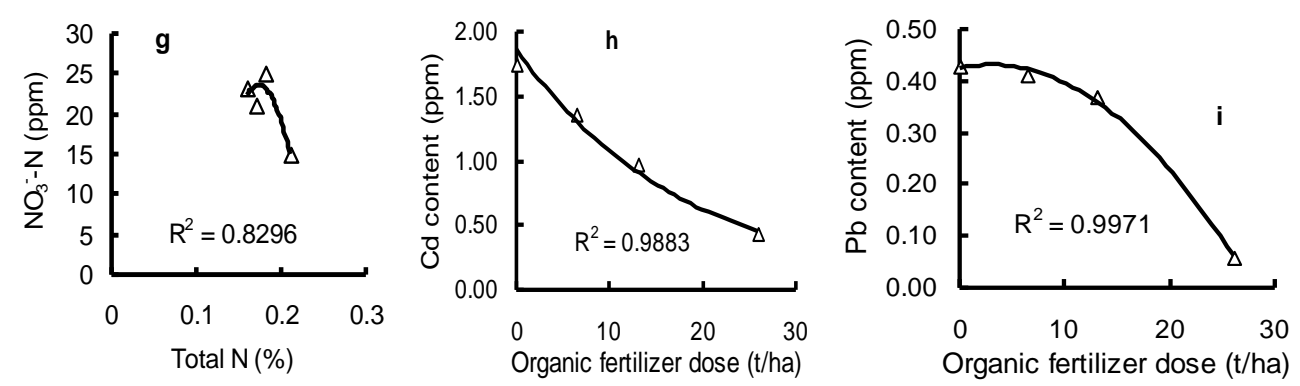

Figure 1. Relationship between plant height and fresh weight of lettuce (a), leaf number and fresh weight of lettuce (b), $\mathrm{NH}_{4}{ }^{+}-\mathrm{N}$ content and dry weight of lettuce (c), $\mathrm{NO}_{3}{ }^{-}-\mathrm{N}$ content and dry yield of lettuce (d), Organic matter and $\mathrm{pH}(\mathrm{e})$, total nitrogen and $\mathrm{NH}_{4}{ }^{+}-\mathrm{N}(\mathrm{f})$, total nitrogen and $\mathrm{NO}_{3}{ }^{-}-\mathrm{N}(\mathrm{g})$, organic fertilizer level and $\mathrm{Cd}$ content (h) and organic fertilizer level and Pd content.

\section{DISCUSSION}

Crop success depends on the availability of nutrients especially nitrogen during growth. Among the organic fertilizers doses, @ $26 \mathrm{t} \mathrm{ha}^{-1}$ produced the lowest yield of lettuce. Reduced growth (plant height and leaf size) of lettuce in this study was directly related to the insufficient dynamics of $\mathrm{N}$ in soil plant-system because the lowest mineral nitrogen content was found in $26 \mathrm{t} \mathrm{ha}^{-1}$ organic fertilizer treated soil. Higher dose $\left(26 \mathrm{tha}^{-1}\right)$ of organic fertilizer produced the maximum organic matter in soil and this increased of organic matter is needed more mineral nitrogen $\left(\mathrm{NH}_{4}{ }^{+}-\mathrm{N}\right.$ and $\left.\mathrm{NO}_{3}{ }^{-}-\mathrm{N}\right)$ for the formation of optimum C:N (10-12:1) ratio in soil, as a result, lettuce growth and development were hampered due to the insufficiency of mineral nitrogen. Researchers reported that $\mathrm{N}$ is the main yield factor and considered as the characteristic constituent of functional plasma, an integral part of chlorophyll molecules, proteins, amino acids, nucleic acids (RNA and DNA), nucleotides, phosphotides, alkaloids, enzymes, coenzymes, hormones and vitamins (Castellanos et al., 2000). After application of higher dose of organic fertilizer, nitrogen immobilization was happened in the first crop season followed by mineralization during the second crop (Lynch et al., 2004). Nitrogen content from supplied organic fertilizer in this experiment was $0.45 \%$. Melgarejo et al. (1997) indicated that low nitrogen enriched $(>2 \%)$ organic materials immobilized mineral nitrogen in soil. On the other hand, organic fertilizer @ $13 \mathrm{t} \mathrm{ha}^{-1}$ produced the maximum lettuce yield. It may be attributed to the potential effect of this amendment level to improve water holding capacity, microbial activity, physicochemical and nutritional properties of soils. Improvement of soil physical, chemical and biological properties was reflected in lettuce growth, yield and nutrient uptake. Our present investigated results indicated that the availability of nutrient was increased in soil when nutrients were supplied 
through optimum organic fertilizer dose. Similar advantage of organic manures in terms of crop growth and nutrient uptake was reported (Haruna, 2011). This could happen due to the synchronization with mineral nitrogen $\left(\mathrm{NH}_{4}{ }^{+}-\mathrm{N}\right.$ and $\left.\mathrm{NO}_{3}{ }^{-}-\mathrm{N}\right)$ and nutritional demands of lettuce crop. Organic fertilizer $\left(26 \mathrm{t} \mathrm{ha}^{-1}\right)$ helped to increase $\mathrm{pH}$ and reduce heavy metals contents in soil except $\mathrm{Zn}$ because organic residues have the potential of transforming electrochemical properties of acidic soils for improving base retention and increasing the soil pH (Krishna et al., 2004). Heavy metals solubility depends on the degree of $\mathrm{pH}$ and dissolves organic matter in soil. Organic matter solubility is relatively low between around $\mathrm{pH} 4.6$ and 6.4 but increase markedly beyond this range to a maximum at $\mathrm{pH}$ 7.7. Linear regression analysis showed that $\mathrm{pH}$ was positively correlated with dissolved organic carbon concentration from 4.6 to $7.7 \mathrm{pH}$ range. Dissolve organic matter increased with the increase of $\mathrm{pH}$ in soil because $\mathrm{pH}$ increases the negative charge on such surfaces is increased and repels negatively charged molecules into the soil solution, thereby increasing dissolve organic matter concentration. Cadmium showed the lowest solubility in soil by the high $\mathrm{pH}$ and high solubility of dissolve organic carbon. These results indicated that $\mathrm{pH}$ showed a strong relationship (negative) with $\mathrm{Cd}$ concentrations in soil (Ashworth and Alloway, 2008). But the inconsistent results were found in respect of Pd concentration in soil. These phenomena might have happened due to the strong adsorption capacity of solid organic phase in soil.

\section{CONCLUSION}

From the above discussion it may be concluded that the growth and yield of lettuce were the highest in recommended dose of organic fertilizer $\left(13 \mathrm{t} \mathrm{ha}^{-1}\right)$. So, organic fertilizer $\left(13 \mathrm{t} \mathrm{ha}^{-1}\right)$ may be recommended to the growers for getting better yield of lettuce.

\section{ACKNOWLEDGEMENTS}

Financial assistance received from the Korea Research Foundation, Govt. of Korea is gratefully acknowledged.

\section{REFERENCES}

Ashworth, D.J., and Alloway, B.J. (2008). Influence of dissolved organic matter on the solubility of heavy metals in sewage-sludge-amended soils. Communications in Soil Science and plant analysis, 39, 538-550.

Villas Boas, R.L., Passos, J.C., Fernandes, D.M., Bull, L.T., Cezar, V.R.S., and Goto, R. (2004). Doses effects and organic compounds types in lettuce crop in two soils under protect environment. Horticultura Brasileira, 22, 28-34.

Bremner, J.M. (1965). In Methods of Soil Analysis. Am. Soc. Agron., Madison. P. 11791237.

Brito, L.M., Pinto, R., Mourao, I., and Coutinho, J. (2012). Organic lettuce, rye/vetch and Swiss chard growth and nutrient uptake response to lime and horse manure compost. Organic Agriculture, 2(3-4), 163-171. 
Castellanos, J.Z., Uvalle-Bueno, J.X., and Aguilar-Santelises, Y.A. (2000). Manual de interpretacion de analisis de suelos, aguas agricolas, plantas y ECP. $2^{\text {nd }}$ ed. INIFAP, Chapingo, Mexico.

Gomez, K.A., and Gomez, A.A. (1984). Statistical procedures for agricultural research, $2^{\text {nd }}$ ed., John Wiley and Sons, Singapore. p. 98.

Haruna, I.M. (2011). Growth and yield of sesame (Sesamum indicum L.) as affected by poultry manure, nitrogen and phosphorus at Samaru, Nigeria. The Journal of Animal and Plant Sciences, 21(4), 653-659.

Krishna, G.M., Arun, K.M., Kuntal, M.H., Kali, K.B., Prabir, K.G., and Manoranjan, M. (2004). Rice residue- management options and effects on soil properties and crop productivity. Food, Agriculture and Environment, 2(1), 224-231.

Lynch, D.H., Voroney, R.P., and Warman, P.R. (2004). Nitrogen availability from composts for humid region perennial grass and legume-grass forage production. Journal of Environmental Quality, 33, 1509-1520.

Melgarejo, M.R., Ballesteros, M.I., and Bendeck, Y.M. (1997). Evaluacion de algunos parametros fisicoquímicos y nutricionales en humus de lombriz y compost derivados. Revista Colombiana de Quimica, 26(2), 1-11.

Moreira, M.A., Santos, C.A.P., Lucas, A.A.T., Bianchini, F.G., de Souza, I.M., and Viegas, P.R.A. (2014). Lettuce production according to different sources of organic matter and soil cover. Agricultural Sciences, 5(2), 99-105.

Oliveira, E.Q., Souza, R.J., Cruz, M.C.M., Marques, V.B., and Franca, A.C. (2010). Lettuce and arugula yield in consorted systems under organic and mineral fertilization. Horticultura Brasileira, 28, 36-40,

Vilas, B.R.L., Passos, J.C., Fernandes, D.M., Bull, L.T., Cezar, V.R.S., and Goto, R. (2004). Efitos de doses de compostos organicos na producao de alface em dois solos sob ambiente protegido. Horticultura Brasileira, 22, 28-34.

Walkley, A., and Black, I.A. (1934). An examination of the Degtjareff method for determining soil organic matter, and a proposed modification of the chromic acid titration method. Soil Science, 34, 29-38. 